\title{
Qualidade ambiental do solo em áreas com Sistema Agroflorestal e pastagem
}

\author{
Matheus Raucci, Vagner R. Ariedi Junior, Zigomar M. de Souza.
}

\section{Resumo}

A macrofauna edáfica participa ativamente na dinâmica do solo, é sensível, responde com rapidez às alterações no ambiente, refletindo e evidenciando as diferenças nos usos e manejos no solo agrícola. O objetivo deste estudo foi avaliar se os diferentes usos e manejos do solo influenciaram na macrofauna edáfica, em um Sistema Agroflorestal (SAF) desenvolvido para Fruticultura/Madeira e uma área de pastagem. Foram quantificados um total de 169 indivíduos, distribuídos em 6 classes e 11 ordens. No SAF foram registradas 5 classes e 10 ordens e na pastagem 3 classes e 4 ordens. As minhocas, as formigas e os besouros foram os grupos mais abundantes. Os resultados iniciais apontaram que os diferentes usos e manejos do solo diferiram e influenciaram a composição da macrofauna edáfica. $\mathrm{O}$ SAF apresentou a maior diversidade e densidade de macrofauna edáfica.

\section{Palavras-chave: \\ Matéria orgânica, macrofauna do solo, manejo conservacionista.}

\section{Introdução}

Os modelos e as práticas da agricultura moderna brasileira, ainda são responsáveis por intensa degradação ambiental, e as técnicas adotadas alteram a fertilidade, promovem a erosão e a compactação solo e, favorecem a desertificação, reduzindo sua capacidade de recuperação. Como alternativa, os Sistemas Agroflorestais (SAF) vêm se tornando sistemas produtivos que potencializam a produção de forma sustentável, equilibrando ganhos econômicos, sociais e ambientais e, a recuperação de sistemas degradados. A macrofauna edáfica participa ativamente na dinâmica do solo, é sensível, responde com rapidez às alterações no ambiente, refletindo em diferenças nas práticas e manejos adotados, evidenciando processos de degradação, restauração, recuperação e alterações do uso do solo agrícola. O objetivo deste estudo foi avaliar se os diferentes usos e manejos do solo influenciaram na macrofauna edáfica, em um Sistema Agroflorestal (SAF) desenvolvido para Fruticultura/Madeira e uma área de pastagem.

\section{Resultados e Discussão}

O estudo foi desenvolvido na Fazenda da Toca, ItirapinaSP. A coleta ocorreu por meio da extração de monólitos de solo em forma de bloco, com o uso de um gabarito $(0,25 \mathrm{~m} \times 0,25 \mathrm{~m} \times 0,10 \mathrm{~m})$, na camada de vegetação superficial e nas profundidades de 0,00-0,10, 0,10-0,20 e 0,20-0,30 m, em cinco pontos, distanciados 10 metros entre si, em linha. Foram quantificados um total de 169 indivíduos, distribuídos em 6 classes e 11 ordens. No SAF foram registradas 5 classes e 10 ordens e na pastagem 3 classes e 4 ordens. As minhocas, as formigas $e$ os besouros foram os grupos mais abundantes. A classe Insecta (insetos) foi a mais representativa, com 6 ordens, ocorrendo nos dois tratamentos. A ordem Coleoptera (besouros) ocorreu nos dois tratamentos. A ordem Haplotaxida (minhocas) ocorreu nos dois tratamentos, apresentando as maiores abundâncias absolutas, relativas e densidade de indivíduos $^{-m 2}$. São considerados como um dos principais grupos de macroinvertebrados edáficos, pois apresentam alta sensibilidade a alterações de uso e manejo do solo, sendo excelentes bioindicadores ambientais. As práticas conservacionistas de manejo do solo tendem a aumentar as populações de minhocas e sua atividade. O SAF apresentou as maiores Abundâncias absoluta, Abundância relativa, Densidade de indivíduos-m2, Riqueza observada, Riqueza média e Riqueza exclusiva, quando comparado com a pastagem. Com relação aos grupos funcionais da macrofauna edáfica, o SAF também apresentou os maiores valores. A maior diversidade, densidade e grupos funcionais (Detritívoros/Decompositores, Geófagos/Bioturbadores, Predadores/Parasitas, Fitófagos/Pragas) observadas no SAF, deve-se ao manejo agroflorestal adotado, sendo o mais equilibrado, e propiciando melhores condições para a macrofauna edáfica, conforme apresentado na Tabela 1 .

Tabela 1. Índices ecológicos relativos à macrofauna edáfica registrada no Sistema Agroflorestal (SAF) e Pastagem.

\begin{tabular}{lcc}
\hline Macrofauna edáfica & SAF & Pastagem \\
\hline Abundância absoluta & 135 & 34 \\
Abundância relativa (\%) & 45 & 11,3 \\
Densidade (ind -m²) $^{2}$ & 2,70 & 0,68 \\
Riqueza observada & 10 & 4 \\
Riqueza média & 0,77 & 0,31 \\
Riqueza exclusiva & 3 & 0 \\
Detritívoros/Decompositores & 7 & 3 \\
Geófagos/Bioturbadores & 3 & 2 \\
Predadores/Parasitas & 6 & 2 \\
Fitófagos/Pragas & 7 & 3 \\
\hline
\end{tabular}

\section{Conclusões}

Os diferentes usos e manejos do solo diferiram e influenciaram a macrofauna edáfica.

\section{Agradecimentos}

Ao Conselho Nacional de Desenvolvimento Científico e Tecnológico (Pibic/CNPq) pelo apoio financeiro, e à Fazenda da Toca Orgânicos pelo auxílio e apoio logísticos. 